\title{
The relationship between knowledge of HIV, self-perceived vulnerability and sexual risk behavior among community clinic workers in Chile
}

\author{
Relación entre conocimientos sobre VIH, percepción de \\ vulnerabilidad y conductas sexuales de riesgo en trabajadores de \\ salud primaria en Chile
}

Baltica Cabieses ${ }^{1}$, Lilian Ferrer $^{2}$, Luis Villarroel ${ }^{3}$, Helena Tunstall ${ }^{4}$ and Kathleen Norr ${ }^{5}$

1 Universidad del Desarrollo CAS-UDD Chile. Santiago, Chile. bcabieses@udd.cl, bbcv500@york.ac.uk

2 Escuela de Enfermería, Universidad Católica de Chile. Santiago, Chile. lferrerl@uc.cl

3 Universidad Católica de Chile. Santiago, Chile. lv@med.puc.cl

4 Department of Health Sciences, University of York. York, England. helena.tunstall@york.ac.uk

5 Women, Children and Family Health Sciences. College of Nursing. University of Illinois at Chicago

UIC. Chicago. United States. knorr@uic.edu

Received $5^{\text {th }}$ February 2010/Sent for Modification $24^{\text {th }}$ October 2010/Accepted $29^{\text {th }}$ October 2010

ABSTRACT

Objective Testing the hypothesis of an association between knowledge and sexual risk behaviour (SRB) amongst community-clinic workers in Chile, explained by the confounding effect of self-perceived vulnerability to HIV.

Methods A cross-sectional survey was analyzed; it was nested within a quasiexperimental study of 720 community-clinic workers in Santiago. The SRB score combined the number of sexual partners and condom use (coded as "high"/"low" SRB). Knowledge of HIV (a 25-item index) was coded as "inadequate"/"adequate" knowledge. Self-perceived vulnerability to HIV was categorised as being "high"/ "moderate"/"low". Control variables included socio-demographics, religiousness and educational level. Percentages/averages, Chi-square tests and logistic regression (OR-estimations) were used for descriptive, association and confounding analysis.

Results Respondents were $78.2 \%$ female, $46.8 \%$ married and $67.6 \%$ Catholic. Mean age was 38.9 (10.5 SD) and $69 \%$ had university/diploma level. Self-perceived HIV vulnerability was "low" in $71.5 \%$ cases. A negative association between knowledge and SRB was found $(\mathrm{OR}=0.55 ; \mathrm{Cl}=0.35-0.86)$, but self-perceived vulnerability did not have a confounding effect on this relationship. This relationship also persisted after being adjusted for multiple control variables (e.g. age, sex, type of primary centre, educational level, and religiousness).

Conclusions Some community-clinic workers had inaccurate knowledge of HIV, which was associated with SRB. Self-perceived vulnerability did not have a confounding effect; however, future studies should further analyze occupational risk of HIV as a possible driving factor in health workers' perception of their risk. 
Focused training programmes should be developed to enhance basic knowledge of HIV in this group.

Key Words: Primary healthcare, knowledge, HIV, sexual behaviour, self-perception, confounding factor, epidemiology (source: $M e S H, N L M$ ).

\section{RESUMEN}

Objetivo Probar la asociación entre conductas sexuales de riesgo (CSR) y conocimiento de VIH en trabajadores de salud primaria en Chile, y el posible efecto de confusión de auto-percepción de vulnerabilidad hacia VIH en dicha relación. Métodos Estudio transversal anidado en estudio cuasi-experimental de 720 trabajadores de salud de Santiago. Score de CSR combinó número de parejas sexuales y uso de condón. Conocimiento de VIH fue medido mediante índice de 25 preguntas. Percepción de vulnerabilidad hacia VIH fue medida como "alta"/"moderada"/ "baja". Variables socio-demográficas, religiosidad y nivel educativo sirvieron de control. Análisis descriptivo, de asociación y confusión fueron desarrollados mediante estimación de proporciones/medias, prueba de Chi-cuadrado y regresión logística. Resultados El 78,2\% de encuestados era mujer, el 46,8 \% estaba casado y el $67,6 \%$ era católico. Promedio de edad de 38,9 años ( $D S=10,5)$ y el $69 \%$ tenía formación universitaria/técnica. La auto-percepción de vulnerabilidad fue "baja" en el 71,5\% de los trabajadores. Se observó una asociación negativa entre conocimiento y CSR $(\mathrm{OR}=0,55, \mathrm{IC}=0,35-0,86)$ y la vulnerabilidad percibida no fue factor de confusión. La asociación se mantuvo tras ajustar por edad, sexo, tipo de centro primario, educación y religiosidad.

Conclusiones Algunos trabajadores de salud comunitaria tenían conocimiento inadecuado de $\mathrm{VIH}$, que se asoció a CSR. La auto-percepción de vulnerabilidad no fue factor de confusión, pero estudios futuros podrían analizar riesgos laborales de VIH como posible mediador en la percepción de riesgo. Programas de entrenamiento en conocimientos básicos de $\mathrm{VIH}$ y CSR debieran implementarse en trabajadores de salud primaria.

Palabras Clave: Atención primaria de salud, conocimiento, HIV, conducta sexual, vulnerabilidad, factores de confusión, epidemiologia (fuente: DeCS, BIREME).

$\mathrm{H}$ IV is a growing public health problem in Chile. Since its emergence in 1984, up to 2004, 5,043 people have died of AIDS and 15,870 people have been diagnosed with HIV (1). The estimated prevalence of people living with HIV (PLHIV) in Chile by 2003 was 3 per 100 thousand (2). Similar to other Latin-American countries, the main transmission mechanism has been sexual (94.1\% of all PLHIV, equivalent to 5,293 people) $(1,2)$. The most frequent sexual orientation reported among PLHIV has been homosexual; however, the proportion of heterosexual people acquiring HIV has progressively increased $(1,3)$. Vertical mother-to-child and sharing infected needles have been other less reported transmission mechanisms in Chile (1-3). 
The Chilean government has made significant efforts at controlling the epidemic and positive results have been achieved in the treatment of AIDS. The AIDS rate has stabilised since 2001 with the support of The Global Fund (4); conversely, the HIV rate continues to rise, reflecting public health prevention strategies' limited effectiveness $(1,3)$. Chile has lower rates of PLHIV than other Latin-American countries; however, evidence from the Asian and African continents suggests that the absence of effective preventive strategies has allowed accelerated HIV transmission, especially amongst vulnerable groups (1-3).

HIV prevention strategies focused upon health workers may be a significant component of prevention policy. Research has suggested that improving health workers' knowledge of HIV could contribute to controlling the epidemic by enhancing patient education on this topic $(5,6)$. However, the criteria for defining suitable knowledge and the instruments used for measuring knowledge level have varied between studies and research findings have been contradictory. Some studies have suggested that health workers have a "sufficient level" of knowledge $(7,8)$ but others have reported deficient knowledge in several areas like prevention, transmission, diagnosis and treatment $(9,10)$. A few studies in Chile have analyzed secondary and tertiary level health workers' HIV knowledge and found their knowledge to be deficient regarding transmission (11). However, knowledge related to HIV among primary level health care health workers has not been researched in Chile.

As HIV is mostly acquired through sexual transmission in Chile, sexual risk behavior (SRB) needs to be addressed. Two particular SRB have been strongly associated with HIV in the general population: multiple sexual partners (12) and inadequate condom use (1). Such SRB have, however, rarely been analyzed together (13) despite recommendations to consider them combined in HIV control (14). Additionally, most HIV prevention programs for health workers have focused on their work-related behavior, although a recent study in Malawi found that peer group intervention reduced rural health workers' sexual risk taking (15). SRB have not been studied amongst health workers in Chile and no specific preventative SRB intervention has been developed for this group.

Self-perceived vulnerability to HIV has been proposed as being a key factor underlying SRB which may be even more important than knowledge (16). Perceived vulnerability to HIV is based on a person's beliefs about 
their behaviour and the possibility of acquiring HIV infection from such behaviour (17). Perceived vulnerability is a relevant component of the Health Belief Model (19) and, for HIV in particular, a negative association between self-perceived vulnerability to HIV and SRB has been proposed in the general population (16). This would suggest that the less vulnerable to HIV people perceive themselves, the more SRB they would engage in, independent of their HIV knowledge.

The relationship between knowledge, SRB and self-perceived vulnerability to HIV amongst community clinic workers in Chile is not well understood. This study's hypothesis was that there is an association between knowledge and SRB amongst community clinic workers which is confounded by selfperceived vulnerability to HIV.

\section{METHODS}

Type of study

This was an analysis of a cross-sectional survey, nested within a quasi-experimental study design (Mobilizing health workers for HIV prevention in Chile, US-Grant R03-TW006980) and developed by Mano a Mano projects during 2005-2007 at the School of Nursing, Universidad Católica de Chile (UC), in association with the University of Illinois at Chicago. The quasiexperimental design tested the effectiveness of an educational intervention in increasing knowledge and reducing stigma amongst community clinic workers in Santiago, Chile. This paper presents data collected during the baseline phase, before the intervention. Ethics committee approval was obtained from both universities.

Setting and participants

The study was carried out in the south-east metropolitan area of Chile. This area contains $25 \%$ of Santiago's population and has the highest rates of PLHIV, poverty, delinquency and illiteracy in the capital $(1,2,21)$. The study focused on a purposive sample of two of the seven municipalities comprising this area, selected at the recommendation of experts from the Chilean Ministry of Health and the local public health service. La Pintana and Puente Alto were considered to be representative of the south-eastern area of the city and are similar in terms of social, economic and educational characteristics $(20,21)$. 
Study participants were community clinic workers from the two municipalities. This study's inclusion criteria defined community clinic workers as being people who were formally involved in improving community health conditions (22) who had a contract for over 22 hours per week.

Sample size and data collection

Every community clinic worker fulfilling inclusion criteria was invited to participate in the study, first through a personal letter by post and then by a phone call at work (July 2006-April 2007 recruitment period); 720 health workers agreed to participate ( $82.9 \%$ response rate). This sample was larger than that estimated as required for analysing association between knowledge and SRB through logistic regression (23). Power was over $80 \%$, thereby reducing the probability of type 2 error (24).

Each health worker who agreed to participate signed an informed consent form and completed a self-administered questionnaire. Completed questionnaires were returned to a member of the research team inside a sealed envelope coded by participant number. The list matching participant name and number and the completed questionnaires were only available to the research team coordinator (they were kept in a locked drawer at UC).

Variables and measurement (Figure 1)

Figure 1. Model of study variables describing the main results

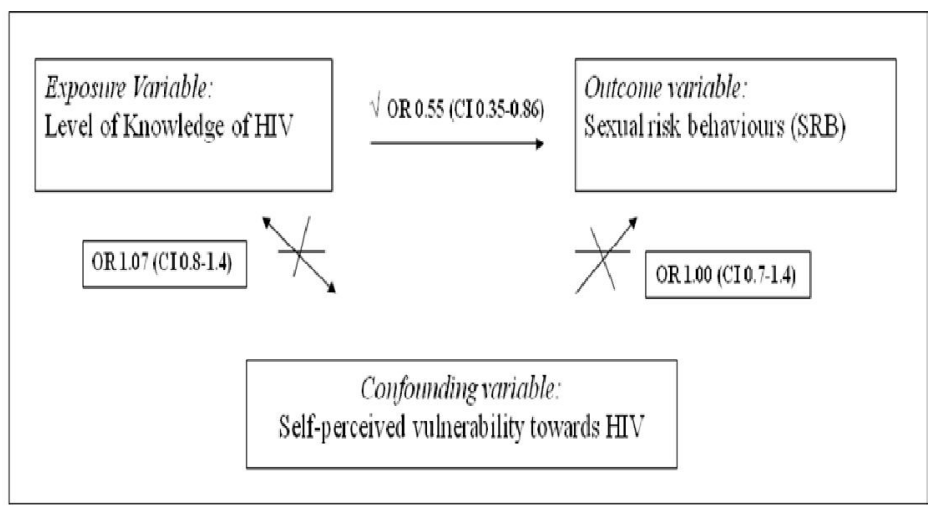

Many of the questionnaire items had been used previously in analysis of HIV prevention for health workers in Africa (US-NIH Grant NR08058, 20012006). Items were added to incorporate new developments such as drug treatment for reducing mother-child transmission. The questionnaire was 
culturally adapted for Chile based on qualitative formative evaluation (25). A modified direct translation method was used for translating the questionnaire into Spanish (26), using a team of bilingual researchers. It was then piloted by the research team in collaboration with HIV experts and community leaders from the area.

Outcome variable: sexual risk behavior (SRB). The SRB score (0-6 points) was based upon the combined number of sexual partners $(0,1,2$ or 3 , which was the higher number reported during the past three months) and condom use (never $=3$, less than $50 \%$ of the time $=2$, more of $50 \%$ of the time $=1$, always $=0$ ) during the last three months. Such variable, constructed in this manner, has been successfully used in previous research (13). Zero points expressed no SRB (equivalent to abstinence) and 6 points expressed the highest possible SRB, equivalent to three or more sexual partners and never using condom during the last three months. The score was recorded in two categories using percentile 50 as a cut-off point (equivalent to 4 points). SRB were then analyzed as a dichotomous variable: "low SRB" less than 4 points and "high SRB" equal to or more than 4 points.

Exposure variable: knowledge of HIV. A 25-item index related to general and occupational knowledge of HIV prevention, transmission and diagnosis was used. Each item on the index could be answered "true", "false" or "don't know". Correct answers were coded as one (1) and incorrect/don't know answers were coded as zero. Kuder-Richardson reliability coefficient of this Spanish version was 0.60 . The knowledge index was dichotomized to discriminate between low and high SRB using a cut-off point defined through localization ROC (LROC) analysis. Such analysis identified the point of highest sensitivity and specificity rates by estimating the area under the curve. The best cut-off point was estimated at percentile 25 , equivalent to 17 points of the scale. The score was then recoded as being "inadequate knowledge" (less than 17 points) and "adequate knowledge" (equal to or greater than 17 points).

Confounder variable: self-perceived vulnerability to HIV. Self perceived vulnerability to HIV was defined by an ordinal variable having three categories: "high", "moderate" and "low", obtained from the question: "What is your probability of contracting HIV?"

Control variables. Age, gender, marital status, educational level, religion, and religiousness (how important is religion in personal decisions, "important" or "not important"), and type of primary clinic. 
Statistical analysis. Exploratory analysis assessed missing and aberrant data which accounted for less than $5 \%$ of total cases. Descriptive analysis obtained means or percentages with standard deviations or $95 \%$ confidence intervals. Outcome, exposure and confounding variables were stratified by the control variables using Chi-square tests or t-tests. If stratified analysis showed significant differences, then logistic regression was adjusted in order to estimate association direction and magnitude. The association between knowledge and SRB was estimated through a $2 \times 2$ table with a Chi-square test and by estimating the odds ratio (OR) with its $95 \%$ confidence interval.

Confounding analysis was developed first by analysing whether self-perceived vulnerability to HIV was independently related to knowledge and SRB. Then, self-perceived vulnerability was included as a co-variable in the logistic regression model to assess changes in the direction and magnitude of the association between knowledge and SRB as a result of the confounding effect (27). STATA software (version 10) was used for completing the data analysis.

\section{RESULTS}

Most participants were female (78.2\%) and their mean age was 38.9 (10.5 SD). Sixty-nine percent of the sample had University or Diploma level education. Most participants were married (46.8\%: $28.9 \%$ were single); 67.6 $\%$ of the group were Catholic and $76.3 \%$ described religion as being important. Table 1 gives more descriptive details.

Knowledge of HIV

As described previously, $75 \%$ of the sample reported an adequate level of HIV knowledge. The three items having the lowest percentage of correct answers were: acquiring HIV through syringes can be reduced if they are disinfected with chlorine before and after use ( $8 \%$ ), the ELISA test does not confirm HIV diagnosis $(26.2 \%)$ and having a caesarean section reduces the risk of transmitting HIV to the baby compared to vaginal delivery $(29.3 \%)$ (Table 2).

Sexual risk behaviour (SRB)

As described in Methods, $50 \%$ of the sample reported high SRB. Stratified analysis showed no difference in SRB by age, sex, educational level, religion and religiousness and type of primary clinic. However, significant differences were observed in terms of marital status as married and cohabitant 
health workers showed a higher prevalence of high SRB compared to single, widowed and divorced health workers $(\mathrm{p}<0.05)$

Self-perceived vulnerability to HIV

Most health workers perceived themselves as having "low" vulnerability to HIV $(71.5 \%)$ and only $10 \%$ reported "high" self-perceived vulnerability to HIV. The other variables included in the stratified analysis were not significantly associated with self-perceived vulnerability.

Table 1. Socio-demographic and occupational characteristics of the sample $(n=720)$

\begin{tabular}{|c|c|}
\hline Characteristics & $\%$ (Frequency) \\
\hline \multicolumn{2}{|l|}{ Marital status } \\
\hline Married & $46.8(337)$ \\
\hline Never married & $28.9(208)$ \\
\hline Divorced & $11.3(81)$ \\
\hline Cohabiting couple & $9.9(71)$ \\
\hline Widow & $2.8(20)$ \\
\hline \multicolumn{2}{|l|}{ Educational level/Type of occupation } \\
\hline Primary school & $0(0)$ \\
\hline Secondary school & $3.4(25)$ \\
\hline High school & $27.2(196)$ \\
\hline Diploma & $31.6(228)$ \\
\hline University & $37.7(271)$ \\
\hline \multicolumn{2}{|l|}{ Religion } \\
\hline Catholic & $68.0(487)$ \\
\hline Atheist & $16.3(117)$ \\
\hline Evangelist & $7.9(57)$ \\
\hline Protestant & $1.2(9)$ \\
\hline Mormon & $1.1(8)$ \\
\hline Jehovah's witness & $0.9(7)$ \\
\hline Other & $4.3(31)$ \\
\hline \multicolumn{2}{|l|}{ Primary Clinics in La Pintana } \\
\hline San Rafael & $11.4(82)$ \\
\hline Pablo de Rokha & $11.7(84)$ \\
\hline Santiago Nueva Extremadura & $11.3(81)$ \\
\hline Santo Tomás & $8.9(64)$ \\
\hline Flor Fernández & $6.4(46)$ \\
\hline \multicolumn{2}{|l|}{ Primary Clinics in Puente Alto } \\
\hline Alejandro del Rio & $14.2(102)$ \\
\hline Manuel Villaseca & $11.8(85)$ \\
\hline Cardenal Raúl Silva Henriquez & $10.3(74)$ \\
\hline San Gerónimo & $10.1(72)$ \\
\hline Vista Hermosa & $4.0(30)$ \\
\hline
\end{tabular}


Association between knowledge and SRB

$71.7 \%$ of the health workers who had an "inadequate" level of HIV knowledge reported high SRB. By contrast, $58.3 \%$ of health workers who had an "adequate" level of knowledge had high SRB ( $\mathrm{p}=0.0082)$. The estimated OR of this association was $0.55(\mathrm{CI}=0.35-0.86)$, indicating that there was $45 \%$ less chance of having high SRB when knowledge was equal to or over 17 points compared to those who had knowledge under 17 points. This association was maintained after adjusting for age, gender, marital status, educational level, religion, religiousness and type of clinic.

Table 2. Absolute and relative frequency of correct answers for each item scored regarding HIV knowledge $(n=720)$

\begin{tabular}{|c|c|c|}
\hline Item & Frequency & $\%$ \\
\hline 1. AIDS can be cured by herbs and complementary medicine & 640 & 89.5 \\
\hline 2. AIDS is caused by a virus & 682 & 95.1 \\
\hline $\begin{array}{l}\text { 3. A person who looks healthy but has AIDS can trans mit it to } \\
\text { another person }\end{array}$ & 666 & 96.3 \\
\hline 4. A person can live with HIV and not be aware of it & 699 & 97.7 \\
\hline $\begin{array}{l}\text { 5. HIV can be passed during sexual intercourse from a person } \\
\text { who lives with the disease to a person who does not if a condom } \\
\text { is not used }\end{array}$ & 692 & 96.3 \\
\hline $\begin{array}{l}\text { 6. HIV can be passed on during sexual intercourse from a person } \\
\text { you know well if a condom is not used }\end{array}$ & 533 & 75.0 \\
\hline $\begin{array}{l}\text { 7. HIV can be acquired through contaminated syringes and } \\
\text { needles if they are not disinfected }\end{array}$ & 638 & 89.1 \\
\hline 8. HIV can by acquired during blood donation & 356 & 49.8 \\
\hline 9. HIV can be acquired though using a public toilet & 629 & 87.4 \\
\hline $\begin{array}{l}\text { 10. A pregnant woman with HIV has much less probability of } \\
\text { passing it to her baby if she receives preventative treatment } \\
\text { during pregnancy }\end{array}$ & 444 & 61.7 \\
\hline $\begin{array}{l}\text { 11. Caesarean delivery reduces the risk of the mother transmitting } \\
\text { HIV to her baby }\end{array}$ & 210 & 29.3 \\
\hline $\begin{array}{l}\text { 12. A newborn can acquire HIV through breastfeeding if the } \\
\text { mother has HIV }\end{array}$ & 469 & 65.5 \\
\hline $\begin{array}{l}\text { 13. Not having sex (sexual abstinence) is the only way of } \\
\text { preventing HIV }\end{array}$ & 629 & 87.3 \\
\hline $\begin{array}{l}\text { 14. The ELISA test for HIV identifies specific antibodies even } \\
\text { during the window period }\end{array}$ & 227 & 31.8 \\
\hline 15. Using a condom provides $100 \%$ confidence of preventing HIV & 470 & 65.6 \\
\hline 16. Most people who have HIV look sick & 606 & 84.4 \\
\hline 17. Only homosexual people can acquire HIV & 693 & 96.3 \\
\hline $\begin{array}{l}\text { 18. An HIV positive person who looks healthy and has null viral } \\
\text { blood charge can still transmit it to another person }\end{array}$ & 392 & 55.1 \\
\hline 19. Sexual workers are the only women who can acquire HIV & 700 & 97.3 \\
\hline 20. Intravenous drug users have a higher risk of acquiring HV & 636 & 88.4 \\
\hline $\begin{array}{l}\text { 21. Intravenous drug users can reduce their risk of acquiring HIV } \\
\text { by disinfecting syringes and needles with chlorine before use }\end{array}$ & 58 & 8.0 \\
\hline 22. The ELISA test for HIV confirms a diagnosis of HIV & 188 & 26.2 \\
\hline 23. A person who looks healthy can be living with HIV & 669 & 93.0 \\
\hline 24. Every person who has contact with body fluids should always & & \\
\hline use gloves & 668 & 92.1 \\
\hline $\begin{array}{l}\text { 25. A woman with a single sexual partner can acquire HIV if her } \\
\text { partner has sex with another person }\end{array}$ & 705 & 98.0 \\
\hline
\end{tabular}


Confounding analysis

No relationship was found between self-perceived vulnerability to HIV and knowledge $(\mathrm{p}=0.639)$ or SRB $(\mathrm{p}=0.953)$ in the first stage of confounding analysis. As expected, no change was observed in the direction and magnitude of the association between knowledge and SRB when self-perceived vulnerability to HIV was added to the logistic regression model. Therefore, self-perceived vulnerability to HIV did not behave as a confounding variable in the relationship between HIV knowledge and SRB in this study (Figure 1).

\section{DISCUSSION}

This is one of the first studies examining the association between SRB, knowledge and self-perceived risk of HIV among community clinic workers and used a large scale, high-quality dataset. Community clinic workers were predominantly females having University or Diploma level education; however, the sample contained workers having a range of different educational levels. The study found that knowledge was inversely associated with SRB; however, self-perceived vulnerability to HIV did not have a confounding effect on this association.

Some of the sample's socio-demographic characteristics have been described as emerging risk factors for HIV acquisition in Chile and must be considered $(1,2)$. Twenty-five percent of the sample was defined as having an inadequate HIV knowledge level. There were several areas in which there was inadequate knowledge regarding the ELISA test, vertical transmission and HIV prevention among injecting drug-users. Previous research has produced similar findings regarding areas where health workers were well-informed or had knowledge gaps $(11,28)$. However, responses regarding HIV prevention for injecting drug-users in this study suggested another area of inadequate knowledge amongst Chilean community health workers.

According to this study, a relevant percentage of health workers engaged in high RSB. The score used for measuring SRB combined the number of sexual partners and condom use during the last three months; it has been used in previous studies analyzing adolescents in Colombia and the relationship between SRB and drug consumption (13). However, this study has been the first to consider the association between such measurement of SRB and HIV knowledge amongst health workers from primary-clinics in Chile. Future research should also consider other aspects of SRB which were not included in this study, such as occupational risk, substance use and type of sexual intercourse (29). 
An inadequate level of HIV knowledge was strongly associated with high SRB when compared to those having an adequate level of knowledge $(\mathrm{p}=0.0082)$. Further analysis of the original scores showed the same inverse relationship (OR 0.56; $\mathrm{p}=0.051$, ordinal logistic regression). Self-perceived vulnerability to HIV was not a confounding variable in the association between knowledge and SRB and, therefore, this relationship continued after its adjustment.

Self-perceived vulnerability to HIV is, however, a complex variable. Vulnerability probably encompasses both health workers' personal and occupational vulnerability (30). These dimensions were not entirely analyzed in this study. Consequently, while this study found no overall association between self-perceived vulnerability and knowledge or SRB, different dimensions of self-perceived vulnerability to HIV and knowledge and SRB could emerge as being significant. Future studies should analyze such relationship further.

This study has shown that some community clinic workers in Chile have inaccurate knowledge of HIV and engage in more SRB despite being employed in the health care system. Their lack of knowledge and inability to be good role models regarding HIV risk reduction means that they may not fulfil their potential as HIV prevention leaders who can help clients reduce their risk of HIV infection. Community clinic workers are especially important potential HIV prevention leaders because they have more opportunities than workers in hospitals for interacting with clients when they are not acutely ill or distressed. Focused training programmes should be developed to enhance basic knowledge related to HIV, in particular transmission mechanisms, diagnosis and prevention in injecting drug users and to help health workers reduce SRB, especially amongst those having a very low level of knowledge (less than percentile 25 of the score). Health workers would personally benefit from effective training and their capacity to be educators and role models for the general public would become enhanced

Acknowledgements: We would like to thank the municipalities and primary clinics in La Pintana and Puente Alto, south-eastern Santiago, Chile, Dr Kate Pickett, Senior Lecturer in Epidemiology and Programme leader, PhD Programme in Health Sciences. University of York, UK funding from the National Institutes of Health, USA (Grant R03-TW006980). 


\section{REFERENCES}

1. Comisión Nacional de SIDA (CONASIDA) [Internet]. Resumen de caracterización epidemiológica del VIH/SIDA en Chile, al 31 de Diciembre del 2003. 2004; Disponible en: http://www.minsal.cl Consultado Marzo 2009.

2. UNAIDS. AIDS epidemic update 2009[Internet]. Joint United Nations Programme on HIV/AIDS (UNAIDS) 2009; Disponible en: http://www.unaids.org/en/KnowledgeCentre/ HIVData/EpiUpdate/EpiUpdArchive/2009/default.asp Consultado Enero 2010.

3. Ministerio de Salud de Chile (MINSAL) [Internet]. Evolución del VIH/SIDA Chile, 1986-2005. Departamento de Epidemiología. DIPLAS-MINSAL. 2006; Disponible en: http:// www.minsal.cl Consultado Junio 2007.

4. Comisión Nacional de SIDA (CONASIDA) [Internet]. Estrategia de atención integral a personas que viven con VIH/SIDA. 2006; Disponible en: http://www.redsalud.gov.cl/archivos/ vih/estrategia_atencion_integral_vih_2006.pdf Consultado Marzo 2007.

5. Laraqui $\mathrm{O}$, Laraqui $\mathrm{S}$, Tripodi $\mathrm{D}$, Zahraoui $\mathrm{M}$, Caubet $\mathrm{A}$, Verger $\mathrm{C}$, Laraqui $\mathrm{CH}$. Assessing knowledge, attitude, and practice on occupational blood exposure in care giving facilities, in Morocco. Med Mal Infect. 2008; 38(12): 658-66.

6. Kociæ B, Petroviæ B, Bogdanoviæ D, Jovanoviæ J, Nikiæ D, Nikoliæ M. Professional risk, knowledge, attitudes and practice of health care personnel in Serbia with regard to HIV and AIDS. Cent Eur J Public Health. 2008; 16(3): 134-7.

7. Walusimbi M, Okonsky J. Knowledge and attitude of Nurses caring for patients with HIV/ AIDS in Uganda. Applied Nursing Research. 2004; 17(2): 92-9.

8. Lohrmann C, Välimäki M, Suominen T, Muinonen U, Dassen T, Peate I. German nursing students' knowledge of and attitudes to HIV and AIDS: two decades after the first AIDS cases. Journal of Advanced Nursing. 2003; 31(3): 696-703.

9. Mukherjee J, Eustache F. Community health workers as a cornerstone for integrating HIV and primary healthcare. AIDS Care. 2007; 1(1): S73-82.

10. Barrientos JE. HIV prevalence, AIDS knowledge, and condom use among female sex workers in Santiago, Chile. Cadernos de Saúde Pública. 2007; 23(8):1777-1784.

11. Bernal J, Lukacs I, Malebrán A, Bonacic H. Actitudes y conocimientos sobre el SIDA en una maternidad de Santiago de Chile. Rev Chil de Obst y Ginec. 2006; 54:151-7.

12. Akin M, Fernández MI, Bowen GS, Warren JC. HIV risk behaviors of Latin American and Caribbean men who have sex with men in Miami, Florida, USA. Rev Panam Salud Pública. 2008; 23(5): 341-8.

13. UNAIDS [Internet]. Comportamientos sexuales de los estudiantes de secundaria de Colombia. Análisis de una encuesta nacional. 2002; Disponible en: http:// www.onusida.org.co/otrosproyectos/fondoglobal/fichatecnica8.htm\#_ftnref6 Consultado Mayo 2007.

14. Senn TE, Carey MP, Vanable PA, Urban MA, Sliwinski MJ. The Male-to-Female Ratio and Multiple Sexual Partners: Multilevel Analysis with Patients from an STD Clinic. AIDS Behav. 2001; 14(4):942-8.

15. Rasamimari A, Dancy B, Talashek M, Park CG. Predictors of sexual behaviors among Thai young adults. J Assoc Nurses AIDS Care. 2007; 18(6): 13-21.

16. McKusic J, Coates T. Reported changes in the sexual behavior of me at risk for AIDS. San Francisco. The AIDS behavioral research Project. Public health Rep. 1985; 100(6): 622-629.

17. Gillespie C. Women's HIV risk reduction efforts and traditional models of health behavior: a review and critique. Women's Health. 1997; 3(1): 1-30.

18. UNAIDS [Internet]. Grupos de mayor vulnerabilidad para VIH. 2008, Disponible en: http:// www.onusida.org.co/vulnerabilidad.htm Consultado Abril 2007.

19. Moreno E, Roales-Nieto J. El modelo de creencias de salud: Revisión teórica, consideración crítica y propuesta alternativa: Hacia un análisis funcional de las creencias en salud. Rev Inter Ps y ter Ps. 2003; 3(1): 91-109. 
20. Instituto Nacional de Estadísticas de Chile (INE) [Internet]. Resultados censales censo 2002. Instituto Nacional de Estadística de Chile. 2003, Disponible en: http://www.ine.cl Consultado Enero 2006.

21. Servicio de Salud Metropolitano Sur Oriente de Chile (SSMSO) [Internet]. Misión, población beneficiaria y establecimientos. 2007, Disponible en: http://www.ssmso.cl/ Consultado Junio 2008.

22. World Health Organization (WHO) [Internet]. The world health report 2006-working together for health. 2006, Disponible en: http://www.who.int/whr/2006/en/index.html Consultado en Junio 2008.

23. Tosteson T, Buzas J, Demidenko E, Karagas M [Internet]. Statistics in Medicine, 22 (7). 2003, Disponible en: http://biostat.hitchcock.org/MeasurementError/Analytics/ SampleSizeCalculationsforLogisticRegression.asp Consultado Mayo 2008.

24. Cochran W. Técnicas de Muestreo. (3rd Ed). México: Compañía Editorial Continental; 1980.

25. Ferrer L, Cianelli R, Norr K, Cabieses B, Araya A, Irarrázabal L, Bernales M. Observed Use of Standard Precautions in Chilean Community Clinics. Public Health Nurs. 2009 Sep-Oct; 26(5):440-8.

26. Behling D, Low K, Severino R, Boldt DW, Hardman J. Problem based learning and medical malpractice: does how you've been trained make a difference? Hawaii Med J. 2003; 62(4): 77-9.

27. Irala J, Martínez-González MA, Guillén F. ¿Qué es una variable de confusión? Med Clin Barcel. 2001; 117: 377-385.

28. Castellano A. Actitud de los profesionales de la salud de las dependencias docente asistenciales de la Pontificia Universidad Católica de Chile, frente al SIDA. Rev Horiz de Enferm. 1993; 5: 26-7.

29. Price LN, Reider EE, Robertson EB. Health-risking social behaviors: moving forward. J Abnorm Child Psychol. 2006; 34(4): 487-94.

30. Ministerio de Salud de Chile (MINSAL) [Internet]. Documento de Trabajo: Actualizaciones técnico metodológicas para el Enfrentamiento de la Vulnerabilidad frente al VIH y las ETS. Comisión Nacional del SIDA. 2006, Santiago, Chile. Disponible en: http:// www.minsal.cl Consultado Junio 2007. 